\title{
Technical, Economic, and Environmental Parameters of Excavator-Based Harvester in Function of Engine Speed and Hydraulic Pump Flow
}

\author{
Diego Weslly Ferreira do Nascimento Santos, Domingos Sárvio Magalhães Valente, \\ Haroldo Carlos Fernandes, Amaury Paulo de Souza, Paulo Roberto Cecon
}

\begin{abstract}
Excavators-based harvesters are self-propelled forestry tractors that normally operate at maximum engine speed. This results in maximum hydraulic pump flow regardless of operating conditions. The objective of this work was to quantitatively investigate the technical performance, as well was the economic and environmental outcomes, of excavators-based harvester as a function of engine speed and hydraulic pump flow. Machine operations were analyzed in forest stands with an individual average volume of 0.08 or $0.16 \mathrm{~m}^{3}$ tree $^{-1}$. The machine was operated with engine speeds of 2060,2000, 1950, or $1900 \mathrm{rpm}$ and hydraulic pump flow rates of 300, 295, or $290 \mathrm{~L} \mathrm{~min}^{-1}$. This resulted in 12 different excavator-based harvester configurations. With regards to the technical performance of the machine, a study of times and movements, productivity, hourly fuel consumption, and fuel consumption was performed. Economic outcomes were considered in terms of the operational costs, while environmental impact was determined by carbon dioxide and methane emissions. Optimal excavator-based harvester operating conditions with an average volume of $0.08 \mathrm{~m}^{3}$ tree $e^{-1}$ were determined to be with an engine speed of $2000 \mathrm{rpm}$ and a hydraulic pump flow rate of $295 \mathrm{~L} \mathrm{~min}^{-1}$. With the $0.16 \mathrm{~m}^{3}$ tree $^{-1}$ volume, the best results were obtained with an engine speed of $2000 \mathrm{rpm}$ and a hydraulic pump flow of $300 \mathrm{~L} \mathrm{~min}^{-1}$.
\end{abstract}

Keywords: forest harvest, forest mechanization, fuel demand

\section{Introduction}

The introduction of the excavator-based harvester made it possible to remove large areas of trees in a short period of time, while also improving operational ergonomics and allowing for work to continue 24 hours a day. Such characteristics have made the excavator-based harvester one of the most utilized machines in the Brazilian forestry sector. It should be noted that there are excavator-based harvesters and purpose-built machines. According to Magagnotti et al. (2017), excavators have a lower investment cost and higher operational flexibility, however, research is needed to increase their fuel efficiency.

In recent years, companies have seen an increase in the costs associated with these machines. With typical operational costs exceeding US\$ 100 per hour, harvester use has been linked to an increased cost in wood (Santos et al. 2017). Behind maintenance and labor, the cost of fuel has been reported as a primary expense, as Silva et al. (2014) demonstrated that fuel accounts for approximately $24 \%$ of the total operating cost.

The internal combustion engine of the excavatorbased harvester has also led to environmental concerns. In recent years, machine manufacturers have had to adhere to increasingly stringent gas emissions limits. According to Zhang et al. (2016) and Laschi et al. (2016), harvester operating conditions directly influence the emission of gases, such as carbon dioxide and methane. Furthermore, the output levels of those gases are directly linked to harvester fuel consumption rates. According to Abbas and Handler (2018), during 
the wood production process, most greenhouse gas emissions occur during the wood harvesting phase. This is due to the fossil fuels required to power the forestry harvesters.

Harvesters are typically operated at maximum engine speed, thus resulting in maximum hydraulic pump flow regardless of operating conditions. Silveira et al. (2013) demonstrated that machine operators tend to use maximum acceleration and inadequate gearing, which leads to an increase in fuel consumption. According to Ramos et al. (2016), engine speed significantly influences the daily consumption of sugarcane harvester fuel. With respect to agricultural tractors, the lowest fuel consumption is obtained with the engine running at $80 \%$ of rated power and rotation (Janulevicius et al. 2013).

Based on the above, this research aims to evaluate the technical performance, as well as the economic and environmental outcomes, of an excavator-based harvester as a function of engine speed and hydraulic pump flow operating in both low- and high-volume forest conditions.

\section{Materials and Methods}

\subsection{Study Area Characterization}

The research with the excavator-based harvester was carried out in Brazil in the state of Bahia. The region has an average annual temperature of $24.4{ }^{\circ} \mathrm{C}$ and an average annual rainfall of $1350 \mathrm{~mm}$. The area in which the experimental plots were allocated had flat relief, was populated with hybrid clones of Eucalyptus grandis $\times$ Eucalyptus urophylla, and was planted with a spacing of 4 meters between rows and 2.5 meters between plants. Data collection started at 6:00 am and ended at 3:00 pm. All tests were conducted in the absence of rain. The research was conducted between February 2018 and January 2019.

\subsection{Harvesting System}

Experiments were carried out in a cut-to-length forest harvesting system. The excavator-based harvester was responsible for cutting and processing trees, leaving on the soil surface $6.20 \mathrm{~m}$ long logs. The machine was simultaneously felling four tree lines. For each treament, data were collected from 14 to 16 experimental plots.

\subsection{Experimental Units}

Experiments were performed in forest conditions with Individual Average Volumes (IAV) of 0.08 and $0.16 \mathrm{~m}^{3}$ tree $^{-1}$, and these conditions were considered low and high, respectively. At each volume, excavatorbased harvester operations were performed at four engine speeds 2060, 2000, 1950, and $1900 \mathrm{rpm}$ and three hydraulic pump flows 300, 295, and $290 \mathrm{~L} \mathrm{~min}^{-1}$, resulting in twelve different operating conditions. For each treatment, 13 to 16 experimental plots were demarcated.

The demarcation of experimental plots was determined using simple random seeding. Each plot was rectangular, arranged in four rows of 10 trees each, totaling 40 trees per plot. The number of planting failures, dead trees, broken trees, and forked trees was quantified, with the latter being counted as a single tree.
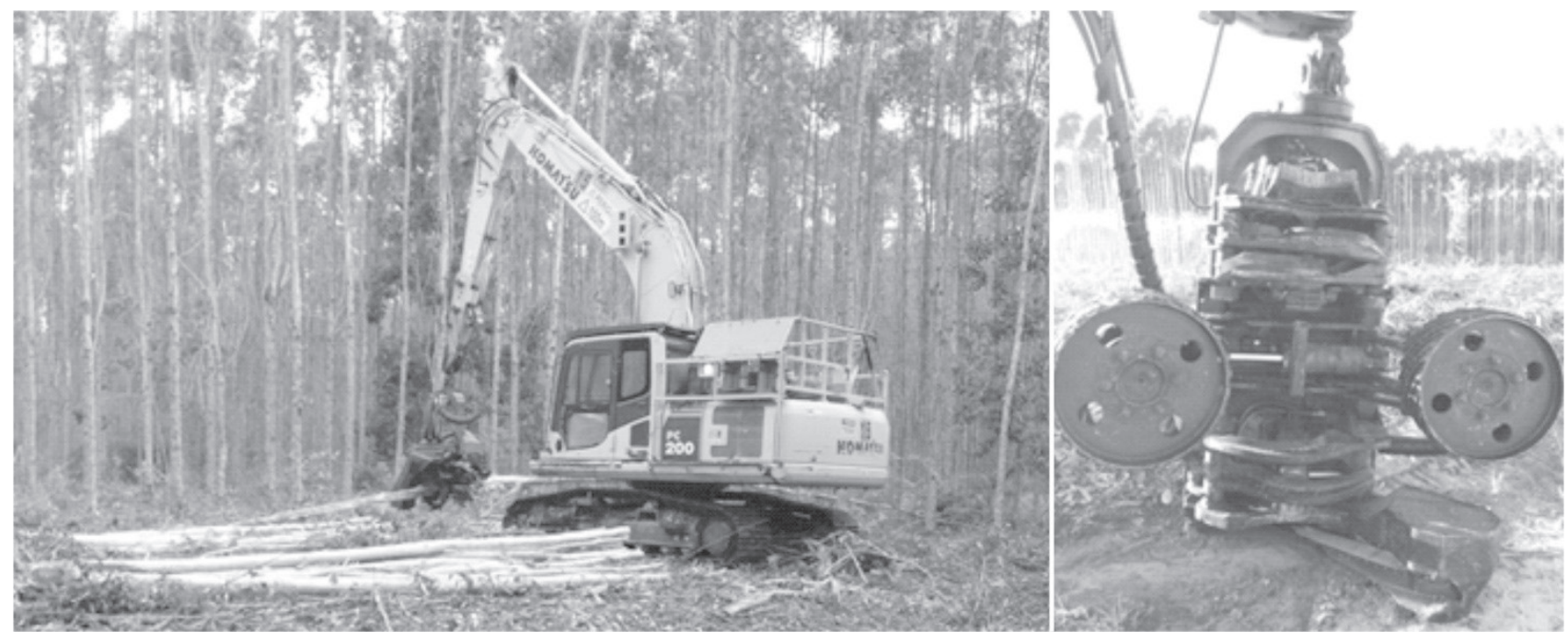

Fig. 1 Excavator-based harvester 


\subsection{Machine Used}

The excavator-based harvester used for the entire experiment was a combination of the Komatsu PC200F$8 \mathrm{M} 0$ hydraulic excavator and the Komatsu 370E harvester head (Fig. 1). The PC200F-8M0 was a crawler machine, powered by the Komatsu SAA6D107E-1 6-cylinder diesel engine with $110 \mathrm{~kW}$ rated power at $2000 \mathrm{rpm}$. The hydraulic system of the machine was Hydraumind type. It consisted of two Komatsu brand HPV95+95 hydraulic pumps, both with variable displacement pistons and a maximum flow for each pump of 219 liters per minute. Only one operator performed the processes for the entire experiment.

\subsection{Machine Instrumentation}

The amount of fuel consumed during the harvester experiment was determined by installing a volumetric flowmeter in the fuel supply system of the engine immediately after the primary filter. The flowmeter used was an $\mathrm{Oval}^{\circledR}$, model LSF41C. A TechMeter LCT model graphic display (indicator) was installed next to the flowmeter for visual feedback. The system was pre-programmed to display and record instantaneous hourly fuel consumption rates and consumption over a given period, reported in liters per hour. The accuracy of the instrument was within $1 \%$.

\subsection{Determination of Individual Tree Volume}

The individual tree volume (IAV) was determined using the diameter and length sensors on the machine head. Later, the IAV was calculated by a MaxiXplorer operating system. The length sensor was positioned on the head feed rollers. The value was measured based on the circumference and rotation of the rollers. The diameter sensor was positioned on the delimbing knives of the head, and the diameter was measured according to the inclination angle of the knives.

To verify the accuracy of the sensors prior to experiments, the harvester cut and processed fifteen trees, and the volume of each tree was measured by the sensors. Subsequently, the diameter and length of the logs were manually quantified using a tape measurer. The volume of the trees was then calculated according to the methodology demonstrated by Husch et al. (2003). No discrepancy was observed between the harvester-derived values and the manually-derived values.

\subsection{Engine Speed Selection}

The engine speed of the excavator-based harvester was adjusted to the values of 2060, 2000, 1950, or 1900 $\mathrm{rpm}$. The engine speed values were controlled by the
MaxiXplorer Machine Information and Control System. The engine speed was altered by the machine throttle button, and the values were displayed on a 12-inch monitor inside the cab.

\subsection{Hydraulic Pump Flow Selection}

Excavator-based harvester operating conditions utilized hydraulic pump flow rates of 300,295, or 290 liters per minute, with changes made directly using the MaxiXplorer Control and Information System, which were visualized on the excavator monitor. Initially, the hydraulic pump was manually tuned to deliver a flow rate of 300 liters per minute at an engine speed of $2060 \mathrm{rpm}$. Later, when necessary, the pump flow rate was changed only by modulating the machine binary value. The hydraulic pump flow was confirmed based on the rotation of the head feed rollers, according to Eq. 1.

Where:

$$
V B=\frac{D e \times 2}{1000} R m
$$

$V B$ hydraulic pump flow, $\mathrm{L} \mathrm{min}^{-1}$

De volume displaced by roller motor, $\mathrm{cm}^{3}$

$\mathrm{Rm}$ feeder roller speed, rpm.

The rotation of the head rollers was determined using a Mimipa digital photo tachometer, model MDT-2244B.

\subsection{Technical Parameters}

The time-motion study was performed using the continuous-time method (BARNES 1968). A video system consisting of four video cameras, a seven-inch monitor, and a Mobile Digital Video Recorder (MDVR) was attached to the excavator. Following operations, the videos were analyzed, and the time required for each operation performed by the machine was measured. The operating cycle of the excavator-based harvester was subdivided into three operations: a) displacement and search, b) felling cut, and c) processing.

The displacement and search cycle starts when the machine finishes processing the tree from the previous cycle or when the machine begins scrolling inside the field in search of a tree to be felled. The operation terminates when the head is positioned on the tree. The felling cut begins when the head is positioned on the tree, with the top and bottom knives as well as the feed rollers attached to the tree. The operation ends when the tree is positioned in a horizontal direction and translocation begins. Processing comprises of peeling, delimbing, tracing, and stacking operations. It begins when the wooden log begins to move down the feed 
rollers in a horizontal direction and ends when the last $\log$ is cut.

A preliminary study was carried out to determine the minimum number of observations required to provide a maximum allowable sampling error of $5 \%$, using Eq. 2 according to the methodology proposed by Barnes (1968).

$$
N^{\prime}=\left[\frac{40 \times N}{\sum X} \sqrt{\frac{\sum X^{2}-\left(\sum X\right)^{2} / N}{N-1}}\right]^{2}
$$

Where:

$N^{\prime}$ number of observations required

$N$ number of observations used in the preliminary study

$X$ value of each observation.

The productivity of the machine was determined in cubic meters of wood per hour of operation $\left(\mathrm{m}^{3} \mathrm{~h}^{-1}\right)$. This metric is provided by the quotient of the volume of the plot $\left(\mathrm{m}^{3}\right)$ and the time spent $(\mathrm{h})$ cutting and processing the trees within the plot. The volume in the plots was calculated by multiplying the number of trees present in the plot and their average individual volume. For each treament, data were collected from 14 to 16 experimental plots.

Hourly fuel consumption $\left(\mathrm{m}^{3} \mathrm{~L}^{-1}\right)$ was calculated by dividing the amount of fuel spent per experimental plot (L) by the time spent on that experimental plot. The hourly consumption of the machine was determined simultaneously with the operating efficiency, so the same number of plots was used for both parameters.

Fuel consumption per cubic meter $\left(\mathrm{L} \mathrm{m}^{-3}\right)$ was determined by dividing hourly fuel consumption and machine productivity.

\subsection{Economic Parameters}

The production cost, in US\$ $\mathrm{m}^{-3}$, was determined by the quotient of operating cost and machine productivity.

Operating cost was determined by summing fixed and variable costs. Some variables required for the calculation were provided by the excavator-based harvester manufacturer, and others were obtained through field evaluations. The hourly fuel consumption was the only altered variable in the twelve treatments studied; all others were kept constant. This measure was intended to verify the isolated effect of hourly fuel consumption on operating costs. In order to provide the costs in terms of the US dollar, an exchange rate of 1 US $\$=R \$ 3.915$ was utilized, as quoted on 03/27/2019.
For the fixed costs, the cost of depreciation, interest, insurance, security, administrative personnel, operator salary, and maintenance personnel was calculated. For the variable costs, the cost of fuel, hydraulic oil, lubricating oil, grease, chain oil, spare parts, and module area organization was determined.

\subsection{Environmental Parameters}

The amount of carbon dioxide equivalent $\left(\mathrm{CO}_{2 \mathrm{eq}}\right)$ and methane $\left(\mathrm{CH}_{4 \mathrm{eq}}\right)$ emitted by the harvester during timber harvesting was determined according to Eq. 3 (Zang et al. 2016).

$$
Q E=\frac{F A \times C h \times P c c}{P}
$$

Where:

$Q E$ amount of carbon dioxide and methane emitted, $\mathrm{kg} \mathrm{m}^{-3}$

FA emission factor for $\mathrm{CO}_{2 \mathrm{eq}}$ or $\mathrm{CH}_{4 \mathrm{eq}}, \mathrm{kg} \mathrm{TJ}^{-1}$

$\mathrm{Ch}$ hourly fuel consumption, $\mathrm{kg} \mathrm{h}^{-1}$ )

$P c c$ fuel calorific value, TJ $\mathrm{kg}^{-1}$

$P$ productivity, $\mathrm{m}^{3} \mathrm{~h}^{-1}$

A specific carbon dioxide and methane emission factor was established as determined by the Intergovernmental Panel on Climate Change (IPCC 2006).

\subsection{Data Analysis}

The experiment was carried out in a $4 \times 3$ factorial scheme with four engine speeds and three hydraulic pump flow rates, totaling 12 treatments. Experiments were carried out in a completely randomized design (CRD), with 13 to 16 replicates per treatment.

Data regarding the study of times and movements, operating efficiency, hourly fuel consumption, fuel consumption per meter cubic, and production cost, as well as carbon dioxide and methane emissions, were analyzed within each volume using response surface methodology (Hair Júnior et al. 2009). The models were selected based on the significance of the regression coefficients, using the $t$-test and adopting the 5\% probability level, the coefficient of determination, and the behavior of the phenomenon under study. All statistical procedures were performed using the computer program Statistica ${ }^{\circledR} 12$.

\section{Results}

\subsection{Technical Parameters}

The engine speed and hydraulic pump flow had a significant and quadratic effect on the time of the displacement and search operation in both IAVs surveyed (Table 1). Despite the influence of independent 
Table 1 Adjusted time-per-cycle equation as a function of engine speed (ES) and hydraulic pump flow (HPF)

\begin{tabular}{|c|c|c|c|}
\hline IAV, $\mathrm{m}^{3}$ tree $^{-1}$ & Operation & Regression equation & $R^{2}, \%$ \\
\hline \multirow{3}{*}{0.08} & Displacement and search & $7.72+5.69110^{-6}{ }^{*} E S^{2}+2.5610^{-4} * H P F^{2}-7.98610^{-5 *} E S H P F$ & 82 \\
\hline & Felling cut & $3.97+4.9710^{-6}{ }^{*} E S^{2}+2,33910^{-4} * H P F^{2}-6.86710^{-5}{ }^{*} E S$ HPF & 69 \\
\hline & Processing & $215.54-9.0510^{-2 * *} E S+1.8010^{-5 * *} E S^{2}-7.6410^{-1 * *} H P F+1.0910^{-3 * *} H P F^{2}+5,85710^{-5 * *} E S$ HPF & 99 \\
\hline \multirow{3}{*}{0.16} & Displacement and search & $15.9922-1.05810^{-6 * *} E S^{2}-6.8410^{-5 * *} H P F^{2}$ & 82 \\
\hline & Felling cut & $8.57-2.51410^{-7 * *} E S^{2}-1.48310^{-5 * *} H P F^{2}$ & 85 \\
\hline & Processing & $25.72+1.4210^{-5}{ }^{*} E S^{2}+6.3810^{-4} * H^{*} F^{2}-2.03610^{-4}{ }^{*} E S$ HPF & 90 \\
\hline
\end{tabular}

Where: ${ }^{*}=$ significant at $5 \%$ probability level; ${ }^{* *}=$ significant at $1 \%$ probability level; $R^{2}=$ coefficient of determination

variables, in the volume of $0.08 \mathrm{~m}^{3}$ tree ${ }^{-1}$, the operating time values were similar when the machine was running at an engine speed above $1950 \mathrm{rpm}$ and hydraulic pump flow was above $295 \mathrm{~L} \mathrm{~min}^{-1}$ (Fig. 2a). At a volume of $0.16 \mathrm{~m}^{3}$ tree ${ }^{-1}$, the lowest value, $5.35 \mathrm{~s} \mathrm{cycle}^{-1}$, was observed when the machine was set to work with engine speed at $2060 \mathrm{rpm}$ and $300 \mathrm{~L} \mathrm{~min}^{-1}$ hydraulic pump flow (Fig. $2 b$ ). In other combinations, the values obtained demonstrate negative impacts on the operation time.

The engine speed and hydraulic pump flow had a significant and quadratic effect on the time of the felling cut operation in both volumes surveyed (Table 1). At the $0.08 \mathrm{~m}^{3}$ tree $^{-1}$ volume, it was found that it was possible to perform the felling operation in almost all

a)

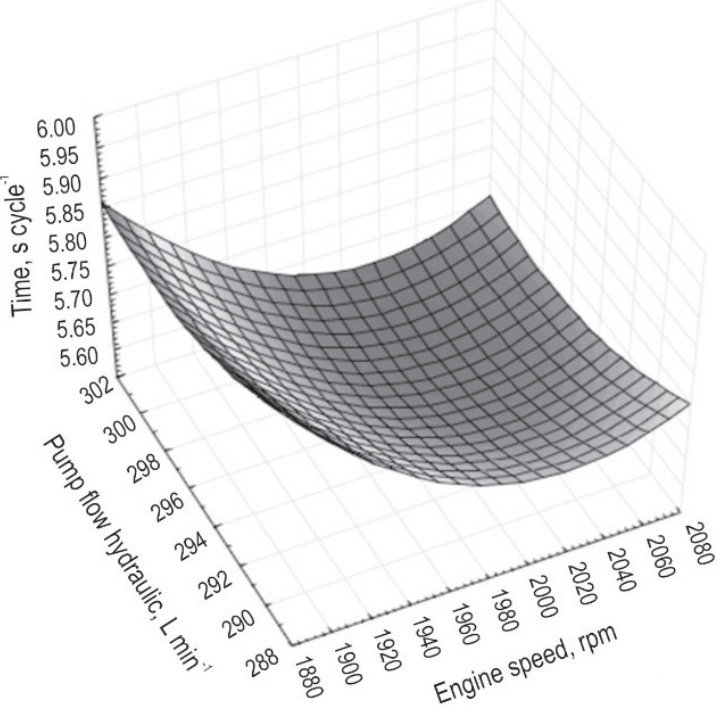

combinations studied, except for the engine speed of $1900 \mathrm{rpm}$ with a pump flow of 300, 295, and $290 \mathrm{~L} \mathrm{~min}^{-1}$ (Fig. 3a). At the $0.16 \mathrm{~m}^{3}$ tree ${ }^{-1}$ volume, the operating time values are similar at the engine speed combinations of $2060 \mathrm{rpm}$ with a pump flow rate of 300 or $295 \mathrm{~L} \mathrm{~min}^{-1}, 2000 \mathrm{rpm}$ with 300 or $295 \mathrm{~L} \mathrm{~min}^{-1}$, and $1950 \mathrm{rpm}$ with $300 \mathrm{~L} \mathrm{~min}^{-1}$ (Fig. 3b).

Engine speed and pump flow had a significant, quadratic and negative effect on processing time in both volumes surveyed (Table 1). In the volume of $0.08 \mathrm{~m}^{3}$ tree $^{-1}$ the shortest time, $10.57 \mathrm{~s} \mathrm{cycle}^{-1}$, was observed with an engine speed of $2060 \mathrm{rpm}$ and a pump flow rate of $295 \mathrm{~L} \mathrm{~min}^{-1}$ (Fig. 4a). A similar value, $10.59 \mathrm{~s} \mathrm{cycle}^{-1}$, was observed in the combinations of a $2060 \mathrm{rpm}$ engine speed with a $295 \mathrm{~L} \mathrm{~min}^{-1}$ pump flow

b)

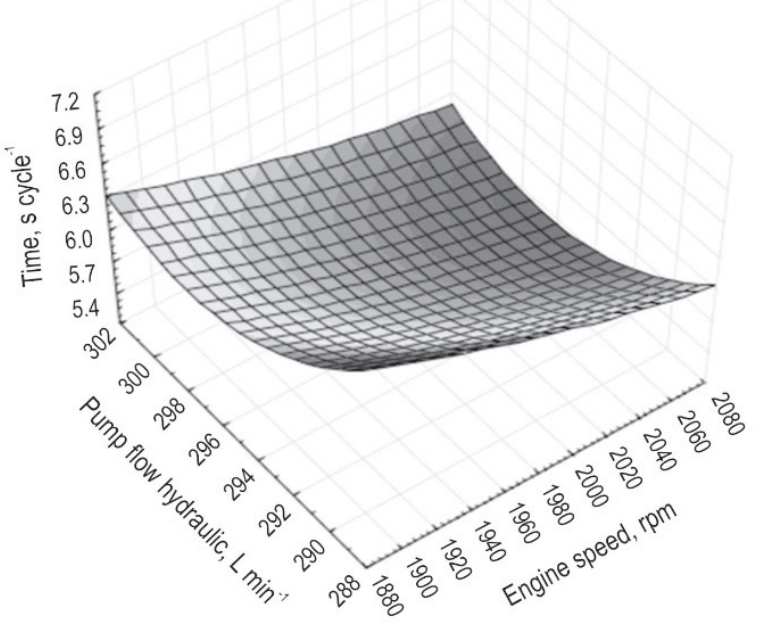

Fig. 2 Time response surface per cycle of displacement and search operation as a function of engine speed and pump flow; a) individual average volume of $0.08 \mathrm{~m}^{3}$ tree $\left.^{-1}, \mathrm{~b}\right)$ individual average volume of $0.16 \mathrm{~m}^{3}$ tree $^{-1}$ 
a)

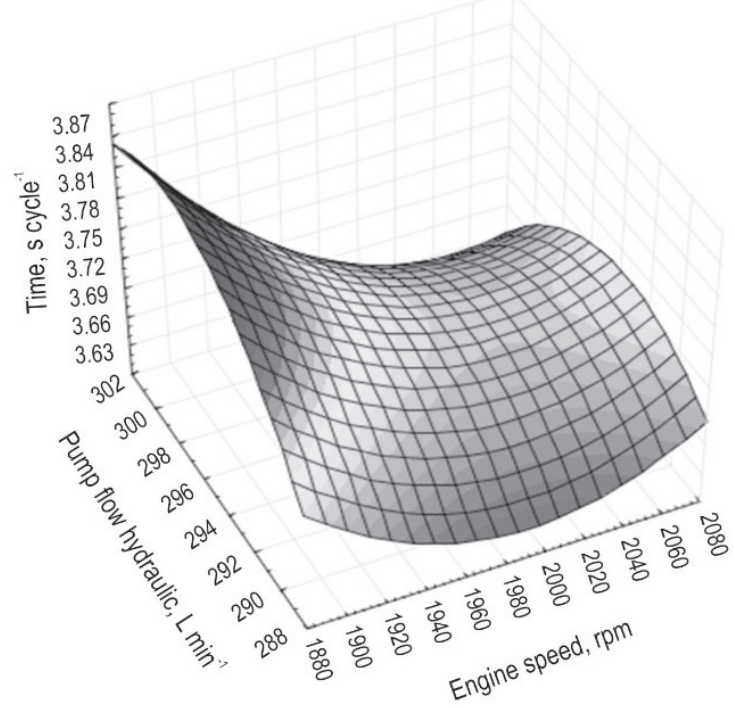

b)

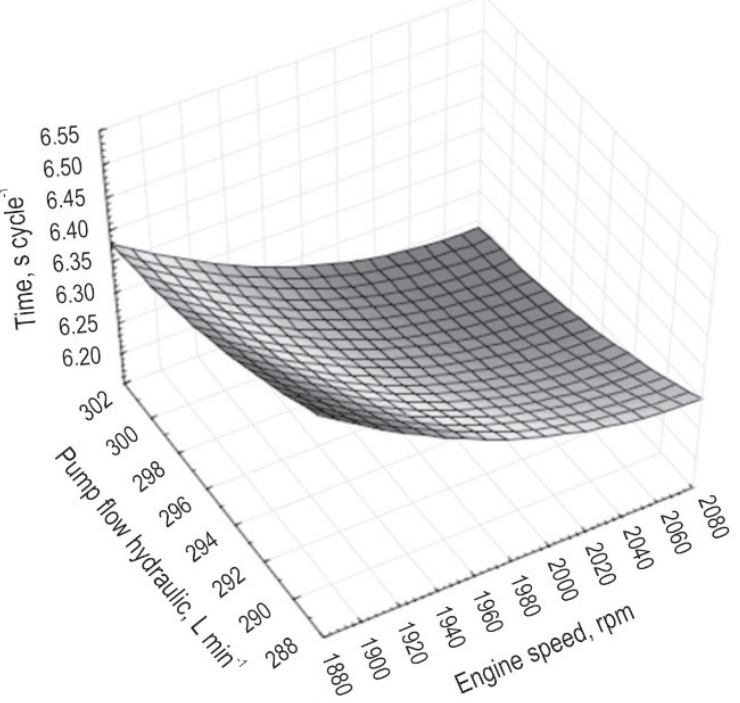

Fig. 3 Time response surface per cycle of felling cut operation as a function of engine speed and pump flow; a) individual average volume of $0.08 \mathrm{~m}^{3}$ tree $\left.^{-1}, \mathrm{~b}\right)$ individual average volume of $0.16 \mathrm{~m}^{3}$ tree $^{-1}$

and a $2000 \mathrm{rpm}$ engine speed with pump flow rates of 300,295 , or $290 \mathrm{~L} \mathrm{~min}^{-1}$. In the volume of $0.16 \mathrm{~m}^{3}$ tree $^{-}$ 1 , the minimum point, $17.57 \mathrm{~s} \mathrm{cycle}^{-1}$, was obtained at the engine speed of $2060 \mathrm{rpm}$ with a pump flow rate of $300 \mathrm{~L} \mathrm{~min}^{-1}$ (Fig. 4b). Similarly, 17.77 and $17.78 \mathrm{~s}$ cycle $^{-1}$ operation durations were observed with an engine speed of $2060 \mathrm{rpm}$ and pump flow rate of $295 \mathrm{~L}$

a)

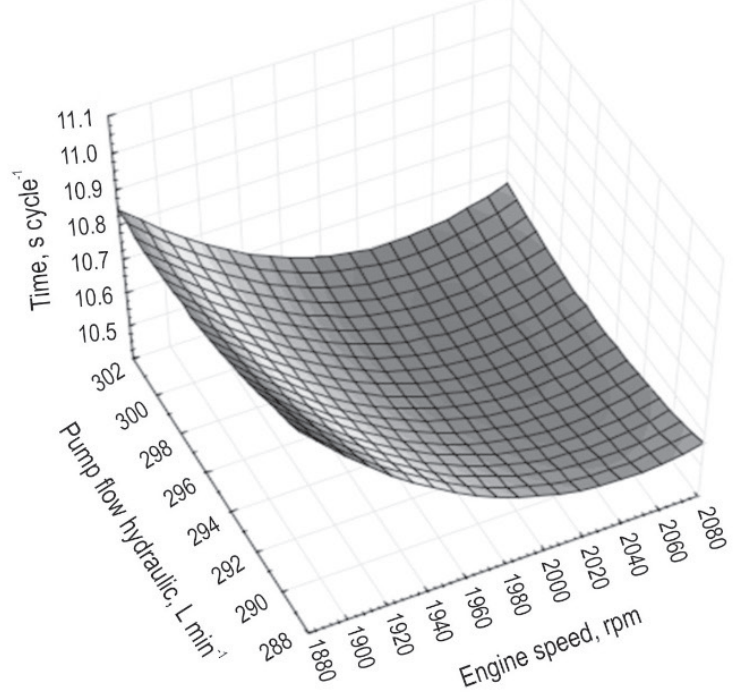

$\mathrm{min}^{-1}$, as well as an engine speed of $2000 \mathrm{rpm}$ with a pump flow rate of $300 \mathrm{~L} \mathrm{~min}^{-1}$, respectively.

Engine speed and hydraulic pump flow had a significant, quadratic and positive influence on machine productivity in the case with a volume of $0.08 \mathrm{~m}^{3}$ tree $^{-1}$ (Table 2). At a higher volume, the engine speed showed a significant and quadratic effect, while the pump flow

b)

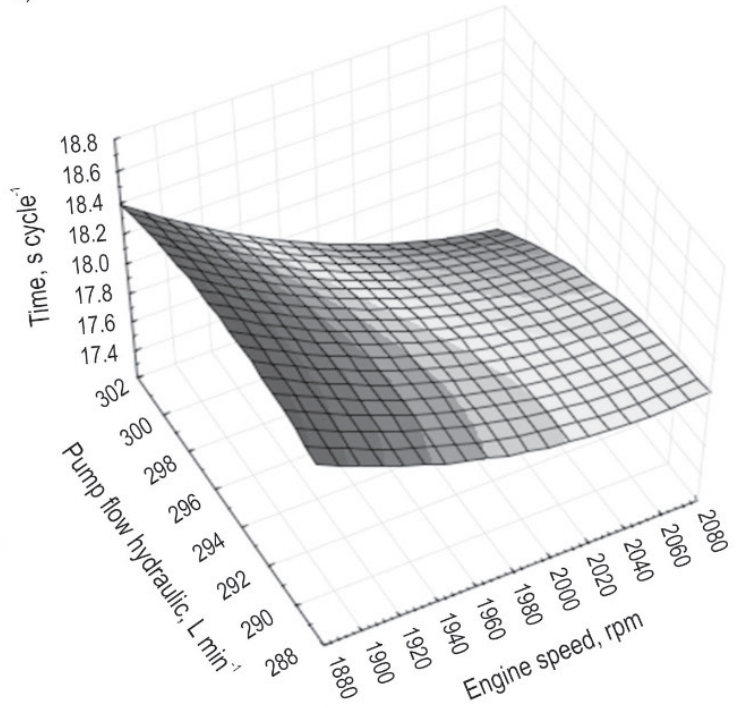

Fig. 4 Time response surface per cycle of processing operation as a function of engine speed and pump flow: a) individual average volume of $0.08 \mathrm{~m}^{3}$ tree $\left.^{-1}, \mathrm{~b}\right)$ individual average volume of $0.16 \mathrm{~m}^{3}$ tree $^{-1}$ 
Table 2 Adjusted equation of productivity, hourly fuel consumption, and fuel consumption per cubic meter as a function of engine speed (ES) and hydraulic pump flow (HPF)

\begin{tabular}{|c|c|c|c|}
\hline$I A V, \mathrm{~m}^{3}$ tree $^{-1}$ & Parameter & Regression equation & $R^{2}, \%$ \\
\hline \multirow{3}{*}{0.08} & Productivity, $\mathrm{m}^{3} \mathrm{~h}^{-1}$ & $11.21-1.0410^{-5}{ }^{*} E S^{2}-4.5310^{-4}{ }^{*} H P F^{2}+1.44910^{-4}{ }^{*} E S$ HPF & 82 \\
\hline & Hourly fuel consumption, $\mathrm{L} \mathrm{h}^{-1}$ & $-43.5096+1.4610^{-2 * *} E S+1.18910^{-1 * *} \mathrm{HPF}$ & 98 \\
\hline & Fuel consumption, $\mathrm{L} \mathrm{m}^{-3}$ & $-3.76310^{-1}+1.62410^{-6}{ }^{*} E S^{2}+7.4110^{-5} * H P F^{2}-1.90610^{-5}{ }^{*} E S$ HPF & 98 \\
\hline \multirow{3}{*}{0.16} & Productivity, $\mathrm{m}^{3} \mathrm{~h}^{-1}$ & $-38.4+1.87610^{-1 * *} H P F+1.5610^{-6 * *} E S^{2}$ & 89 \\
\hline & Hourly fuel consumption, $\mathrm{L} \mathrm{h}^{-1}$ & $-19.7978+5.110^{-3 * *} E S+1.09810^{-1 * *} \mathrm{HPF}$ & 98 \\
\hline & Fuel consumption, $\mathrm{L} \mathrm{m}^{-3}$ & $1.96-7.8610^{-8 * *} E S^{2}-7.4910^{-6 * *} H P F^{2}$ & 76 \\
\hline
\end{tabular}

Where: ${ }^{*}=$ significant at $5 \%$ probability level; ${ }^{* *}=$ significant at $1 \%$ probability level; $R^{2}=$ coefficient of determination

rate had a significant and linear effect (Table 2). Despite the influence of the independent variables, with lower individual tree volumes, it is possible to configure the excavator to perform forest harvesting operations with an engine speed between 1950 to $2060 \mathrm{rpm}$ and a pump flow rate between 295 and $300 \mathrm{~L} \mathrm{~min}^{-1}$. Such combinations do not result in a significant decrease in productivity (Fig. 5a). In higher volume conditions, the production values follow with the engine speed-hydralic pump flow combinations of 2060 or $2000 \mathrm{rpm}$ at $300 \mathrm{~L} \mathrm{~min}^{-1}$ (Fig. 5b).

Engine speed and hydraulic pump flow rate had a linear, positive, and significant effect on hourly fuel consumption in all volumes studied (Table 2). Keeping

a)

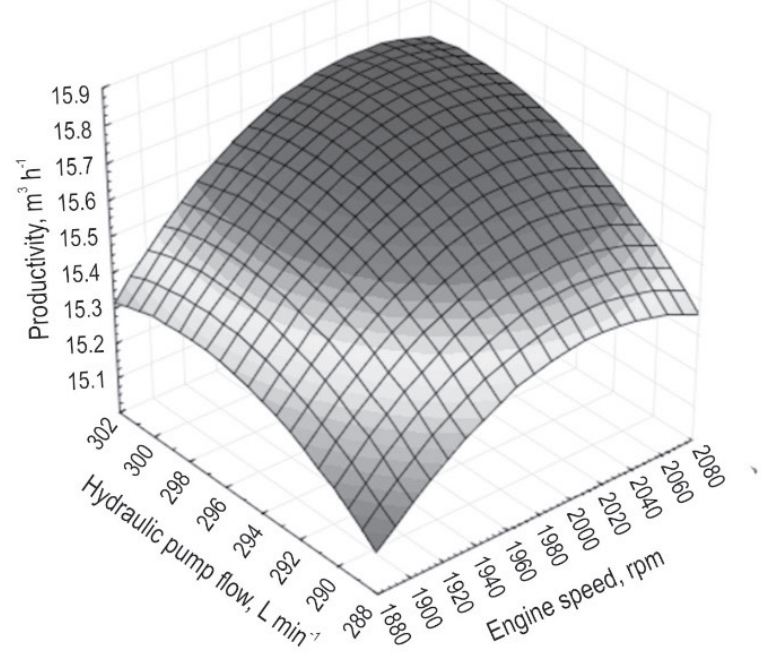

the pump flow rate fixed and decreasing the engine speed at the studied levels presented a mean reduction of $0.78(4.10 \%)$ and $0.27(1.31 \%) \mathrm{L} \mathrm{h}^{-1}$ in hourly consumption for volumes of 0.08 and $0.16 \mathrm{~m}^{3}$ tree ${ }^{-1}$, respectively (Fig. 6). Otherwise, keeping the engine speed fixed and decreasing the pump flow at the studied levels demonstrated an average reduction of 0.59 (2.74\%) and $0.55(2.37 \%) \mathrm{L} \mathrm{h}^{-1}$ in hourly fuel consumption in low and high volumes, respectively.

Engine speed and hydraulic pump flow had a significant quadratic effect on fuel consumption per meter cubic in all scenarios studied (Table 2). With an engine speed of $1900 \mathrm{rpm}$ and a hydraulic pump flow of $290 \mathrm{~L} \mathrm{~min}^{-1}$, the lowest values for fuel

b)

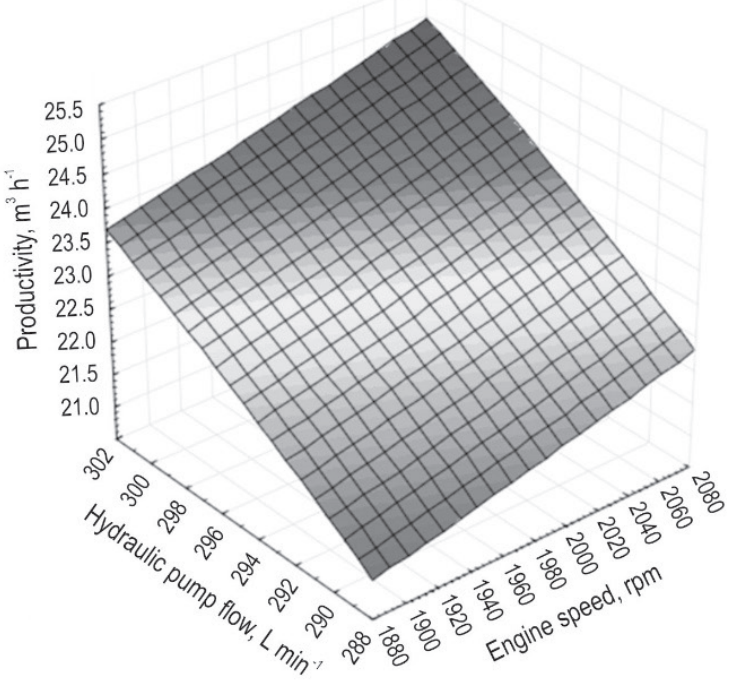

Fig. 5 Response surface of productivity as a function of engine speed and hydraulic pump flow: a) individual average volume of $0.08 \mathrm{~m}^{3}$ tree ${ }^{-1}$, b) individual average volume of $0.16 \mathrm{~m}^{3}$ tree $^{-1}$ 
a)

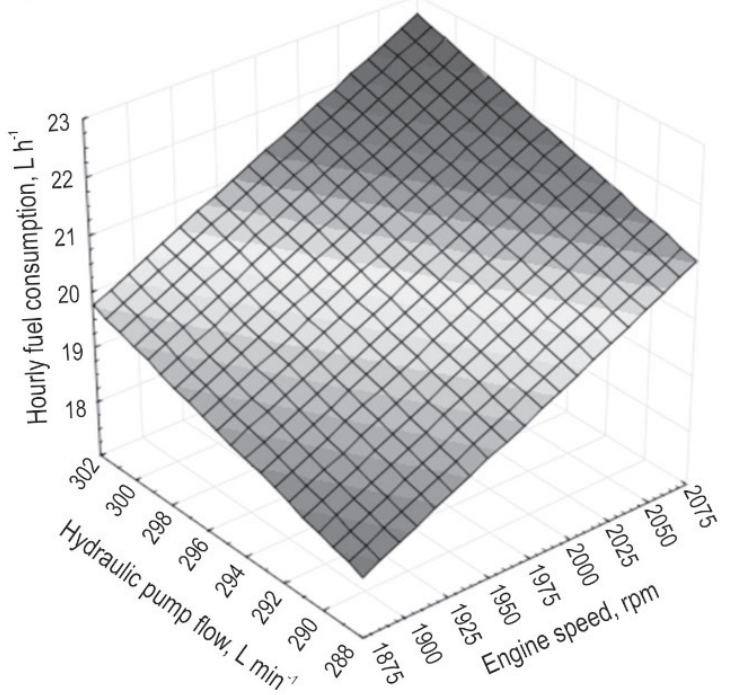

b)

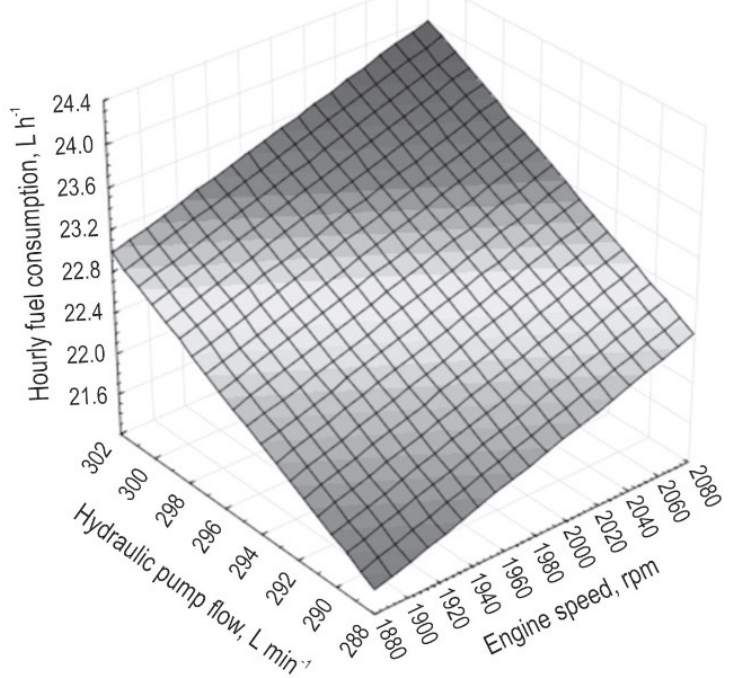

Fig. 6 Response surface of hourly fuel consumption as a function of engine speed (ES) and hydraulic pump flow (HPF): a) individual average volume of $0.08 \mathrm{~m}^{3}$ tree $\left.^{-1}, \mathrm{~b}\right)$ individual average volume of $0.16 \mathrm{~m}^{3}$ tree ${ }^{-1}$

consumption, $1.22 \mathrm{~L} \mathrm{~m}^{-3}$, were obtained for the volume of $0.08 \mathrm{~m}^{3}$ tree $^{-1}$ (Fig. 7a). In the high volume scenario, the lowest fuel consumption, $0.95 \mathrm{~L} \mathrm{~m}^{-3}$, was achieved with an engine speed of $2060 \mathrm{rpm}$ and a pump flow rate of $300 \mathrm{~L} \mathrm{~min}^{-1}$ (Fig. 7b). A similar fuel consumption, $0.97 \mathrm{~L} \mathrm{~m}^{-3}$, was acheived with an engine speed of $2000 \mathrm{rpm}$ and a pump flow rate of $300 \mathrm{~L} \mathrm{~min}^{-1}$.

a)

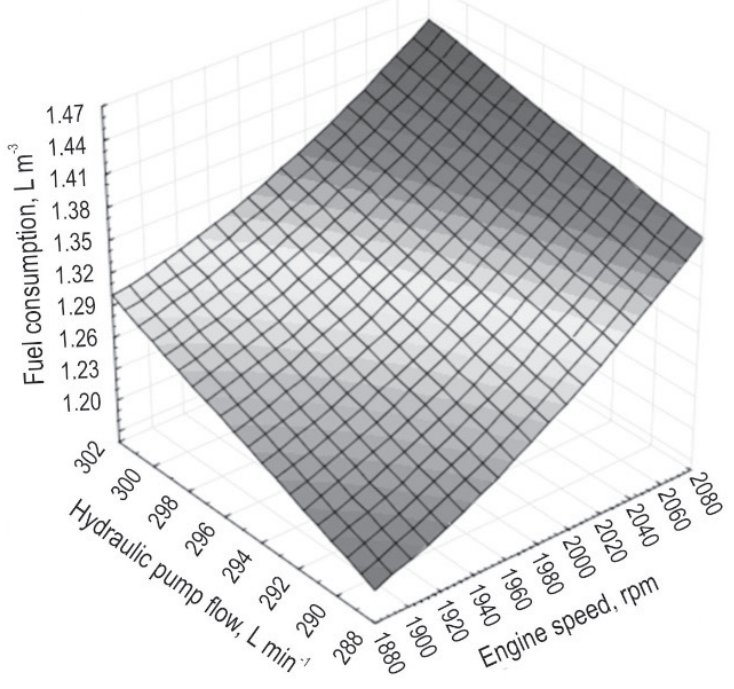

When analyzing fuel consumption per meter cubic values, it was found that in some circumstances, the combination with the lowest fuel consumption value does not provide the best hourly productivity results. In the volume of $0.08 \mathrm{~m}^{3}$ tree $^{-1}$, the combination that provided the lowest value of fuel consumption had a productivity of $0.45 \mathrm{~m}^{3} \mathrm{~h}^{-1}$, which

b)

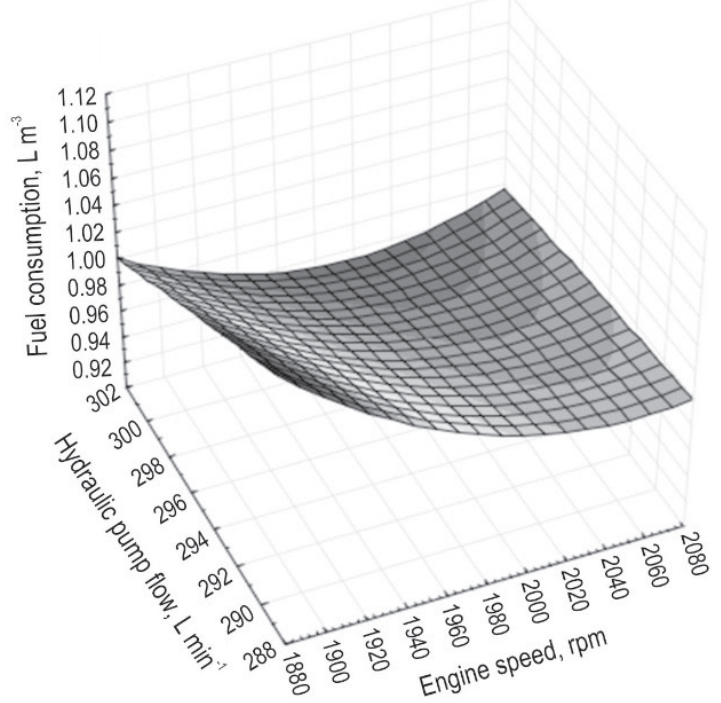

Fig. 7 Response surface of fuel consumption per meter cubic as a function of engine speed and hydraulic pump flow: a) individual average volume of $0.08 \mathrm{~m}^{3}$ tree $^{-1}, \mathrm{~b}$ ) individual average volume of $0.16 \mathrm{~m}^{3}$ tree $^{-1}$ 
Table 3 Adjusted equation of production cost as a function of engine speed (ES) and hydraulic pump flow (HPF)

\begin{tabular}{|c|c|c|c|}
\hline $\mathrm{IAV}, \mathrm{m}^{3}$ tree $^{-1}$ & Parameter & Regression equation & $R^{2}, \%$ \\
\hline 0.08 & Production cost, US\$ $\mathrm{m}^{-3}$ & $5+3.75410^{-6}{ }^{*} E S^{2}+1.65710^{-4} * H P F^{2}-5.005910^{-5}{ }^{*} E S$ HPF & 48 \\
\hline 0.16 & Production cost, US\$ $\mathrm{m}^{-3}$ & $102.23-6.02810^{-2} * * E S-2.2810^{-1}{ }^{*} H P F+7.3810^{-6}{ }^{*} E S^{2}+1.00710^{-4}{ }^{*} E S$ HPF & 97 \\
\hline
\end{tabular}

Where: ${ }^{*}=$ significant at $5 \%$ probability level; ${ }^{* *}=$ significant at $1 \%$ probability level; $R^{2}=$ coefficient of determination

is less when compared to the productivity acheived with an engine speed of $2060 \mathrm{rpm}$ and a pump flow rate of $300 \mathrm{~L} \mathrm{~min}^{-1}$. However, the configuration of $2000 \mathrm{rpm}$ and $295 \mathrm{~L} \mathrm{~min}^{-1}$ resulted in low fuel consumption while also maintaining machine productivity.

\subsection{Economic Parameters}

Engine speed and pump flow had a significant quadratic effect on the production cost with volumes of $0.08 \mathrm{~m}^{3}$ tree $^{-1}$ (Table 3). In the higher volume scenarios, engine speed had a significant and quadratic effect, while pump flow had a significant linear effect (Table 3). With an Individual Average Volume of $0.08 \mathrm{~m}^{3}$ tree $\mathrm{e}^{-1}$, the lowest production cost, US $\$ 4.90 \mathrm{~m}^{-3}$, was obtained with an engine speed of $2000 \mathrm{rpm}$ and a pump flow rate of $300 \mathrm{~L} \mathrm{~min}^{-1}$ (Fig. 8a). The same value was acheived utilizing a configuration with an engine speed of $1950 \mathrm{rpm}$ and a hydraulic pump flow rate $295 \mathrm{~L} \mathrm{~min}^{-1}$. With a volume of $0.16 \mathrm{~m}^{3}$ tree ${ }^{-1}$, the

a)

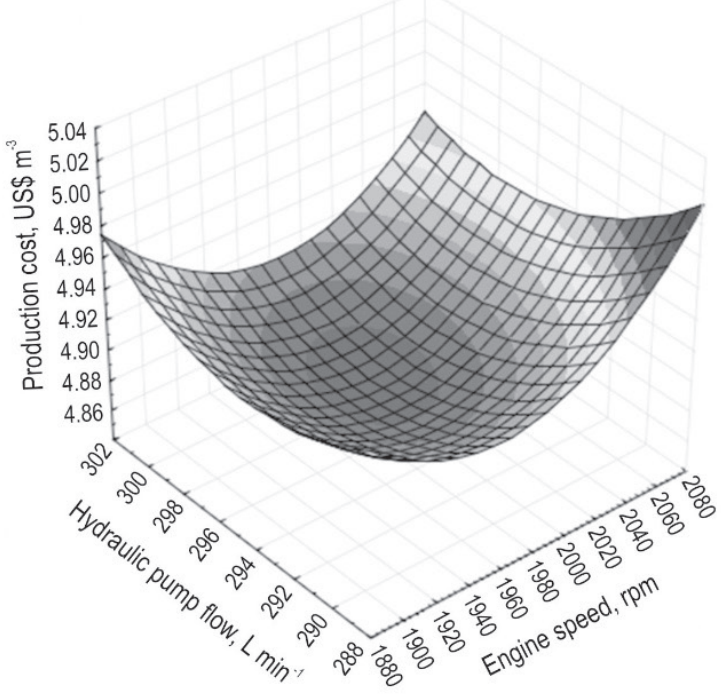

lowest production cost, US\$ $3.20 \mathrm{~m}^{-3}$, was obtained using an engine speed of $2060 \mathrm{rpm}$ and a pump flow rate of $300 \mathrm{~L} \mathrm{~min}^{-1}$ (Fig. 8b). A similar production cost of US\$ $3.21 \mathrm{~m}^{-3}$ was acheived using an engine speed of $2000 \mathrm{rpm}$ and a pump flow rate of $300 \mathrm{~L} \mathrm{~min}^{-1}$.

\subsection{Environmental Parameters}

Engine speed and hydraulic pump flow had a significant quadratic effect on the amount of carbon dioxide and methane emitted per cubic meter of harvested wood in both tree volume conditions (Table 4). With the volume of $0.08 \mathrm{~m} 3$ tree $^{-1}$, the smallest amount of carbon dioxide emissions of $3.39 \mathrm{~kg} \mathrm{~m}^{-3}$ and methane emissions of $0.000189 \mathrm{~kg} \mathrm{~m}^{-3}$ was obtained using an engine speed of $1900 \mathrm{rpm}$ and a pump flow rate of $290 \mathrm{~L} \mathrm{~min}^{-1}$. In the higher tree volume condition, the smallest amounts of $\mathrm{CO}_{2 \mathrm{eq}}$ and $\mathrm{CH}_{4 \mathrm{eq}}$ released, $2.67 \mathrm{~kg} \mathrm{~m}^{-3}$ and $0.000144 \mathrm{~kg} \mathrm{~m}^{-3}$, respectively, were obtained with an engine speed of $2000 \mathrm{rpm}$ and a pump flow rate of $300 \mathrm{~L} \mathrm{~min}^{-1}$.

b)

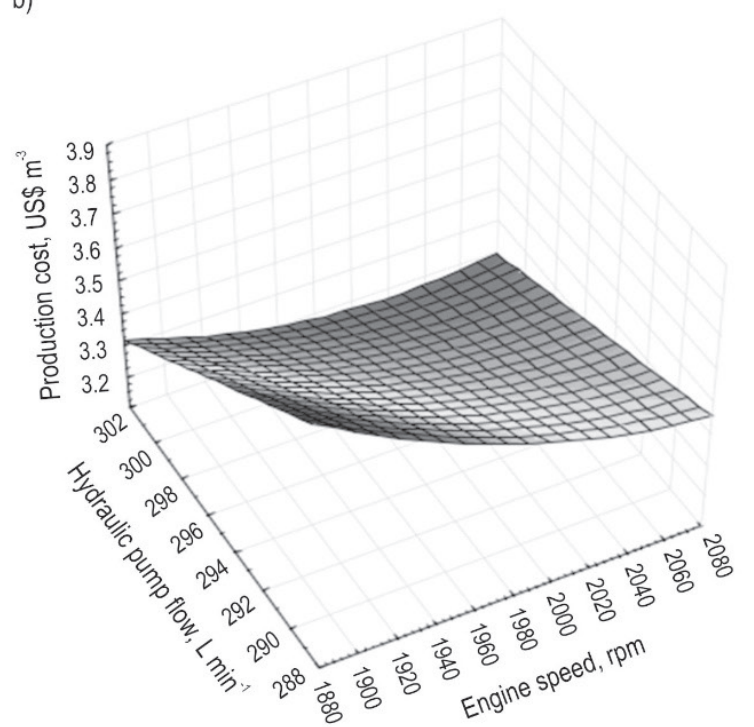

Fig. 8 Response surface of production cost as a function of engine speed and hydraulic pump flow: a) individual average volume of $0.08 \mathrm{~m}^{3}$ tree $^{-1}, \mathrm{~b}$ ) individual average volume of $0.16 \mathrm{~m}^{3}$ tree $^{-1}$ 
D. Santos et al. Technical, Economic, and Environmental Parameters of Excavator-Based Harvester in Function ... (205-218)

Table 4 Regression equation of carbon dioxide and methane as a function of engine speed (ES) and hydraulic pump flow (HPF)

\begin{tabular}{|c|c|c|c|}
\hline$I A V, \mathrm{~m}^{3}$ tree $^{-1}$ & Parameter & Regression equation & $R^{2}, \%$ \\
\hline \multirow{2}{*}{0.08} & Carbon dioxide, $\mathrm{kg} \mathrm{m}^{-3}$ & $-1.04+4.5710^{-6}{ }^{*} E S^{2}+2.0910^{-4} * H P F^{2}-5.3810^{-5} * E S H P F$ & 98 \\
\hline & Methane, $\mathrm{kg} \mathrm{m}^{-3}$ & $-5.8310^{-5}+2.5610^{-10 *} E S^{2}+1.16910^{-8}{ }^{*} H P F^{2}-3.01210^{-9}{ }^{*} E S$ HPF & 98 \\
\hline \multirow{2}{*}{0.16} & Carbon dioxide, $\mathrm{kg} \mathrm{m}^{-3}$ & $48.22-4.35710^{-2}{ }^{*} E S+4.5410^{-6}{ }^{*} E S^{2}-3.0510^{-4} * H P F^{2}+8.4810^{-5}{ }^{*} E S$ HPF & 90 \\
\hline & Methane, $\mathrm{kg} \mathrm{m}^{-3}$ & $2.5610^{-3}-2.310^{-6}{ }^{*} E S+2.4610^{-10 *} E S^{2}-1.610^{-8} * H P F^{2}+4.410^{-9} * E S H P F$ & 91 \\
\hline
\end{tabular}

Where: ${ }^{*}=$ significant at $5 \%$ probability level; ${ }^{* *}=$ significant at $1 \%$ probability level; $R^{2}=$ coefficient of determination

a)

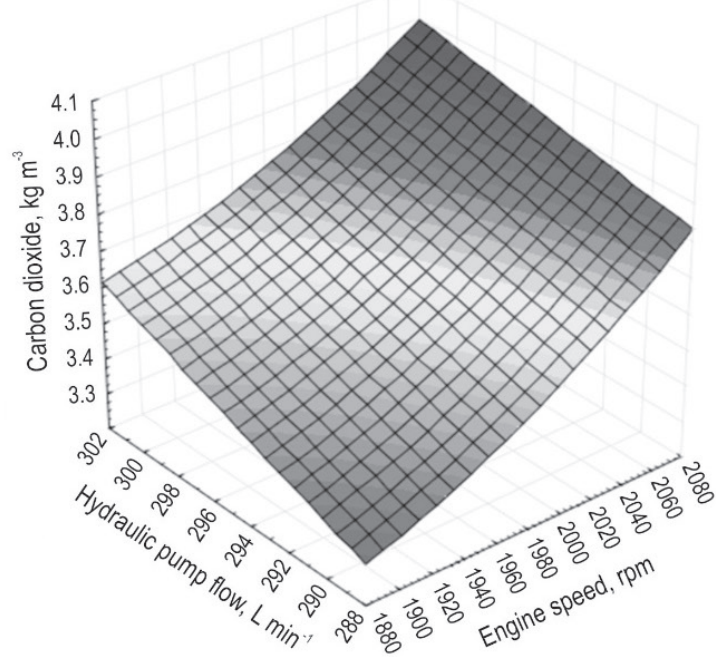

b)

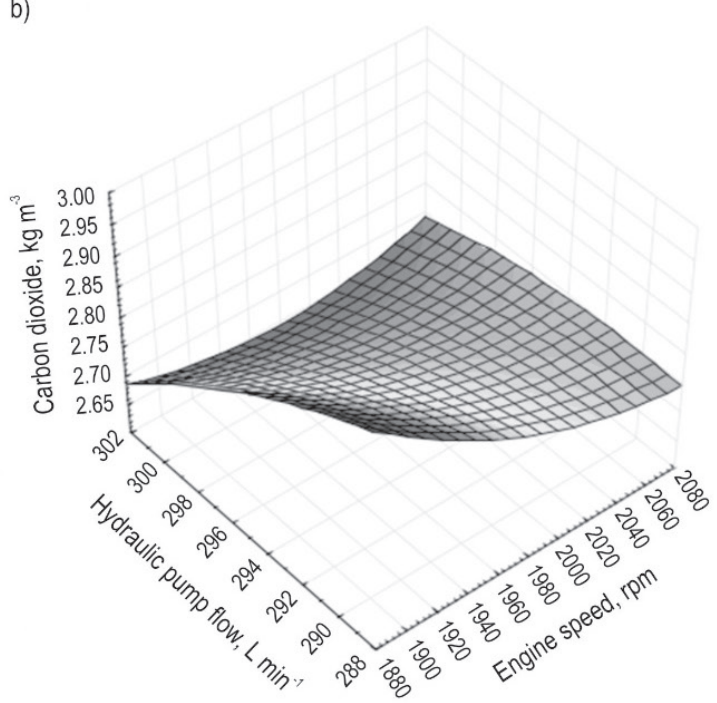

Fig. 9 Response surface of the amount of carbon dioxide emitted as a function of engine speed and hydraulic pump flow: a) individual average volume of $0.08 \mathrm{~m}^{3}$ tree $^{-1}, \mathrm{~b}$ ) individual average volume of $0.16 \mathrm{~m}^{3}$ tree $^{-1}$

a)

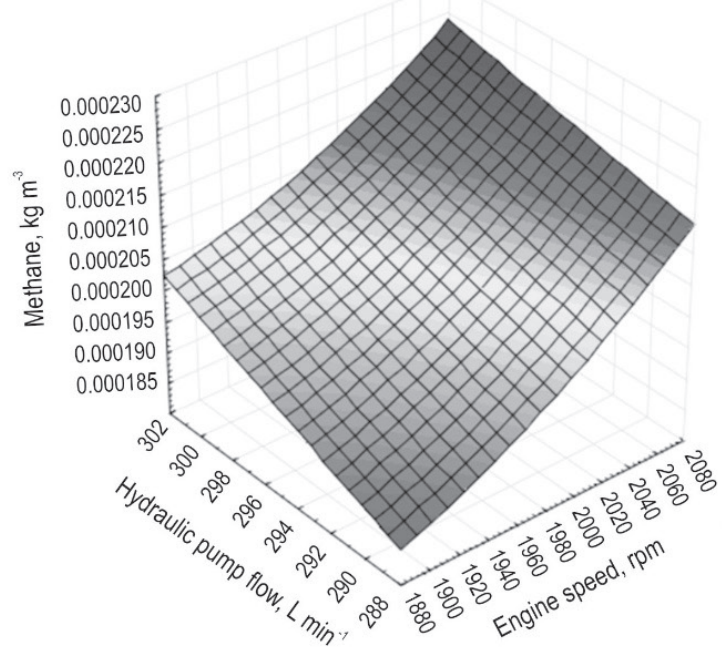

b)

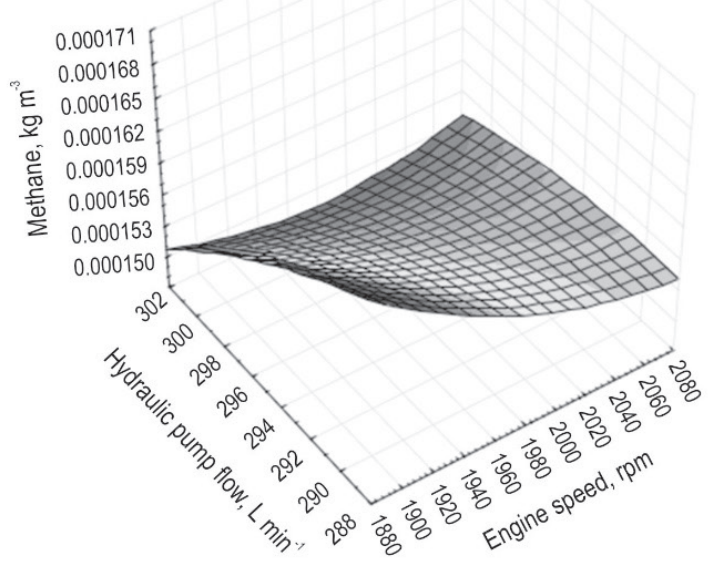

Fig. 10 Response surface of the amount of methane emitted as a function of engine speed and hydraulic pump flow: a) individual average volume of $0.08 \mathrm{~m}^{3}$ tree ${ }^{-1}$, b) individual average volume of $0.16 \mathrm{~m}^{3}$ tree $^{-1}$ 


\section{Discussion}

\subsection{Technical Parameters}

The influence of engine speed and pump flow on the displacement and search operation time is related to the high tractive force required to promote machine speed on the ground surface. This function places the highest demand of all excavator-based harvester operations on the power output of the machine.

Reducing engine speed below $1950 \mathrm{rpm}$ and pump flow below $295 \mathrm{~L} \mathrm{~min}^{-1}$ caused a decrease in head saw speed, and this increased the time for the saw to reach the standard working speed, $6400 \mathrm{rpm}$. Such circumstances caused an increase in the time of the felling cut operation, especially at the higher volume condition because the trees had a larger diameter, and consequently, it demanded a higher saw rotation regime.

The influence of engine speed and pump flow on the time of the processing operation became more expressive with the increase of tree volume. This was due to the greater weight of the wood, which reduced the $\log$ feed speed during processing, mainly at engine speeds of 1950 and $1900 \mathrm{rpm}$ and pump flow rates of 295 and $290 \mathrm{~L} \mathrm{~min}^{-1}$. It is worth mentioning that bifurcated trees with many branches along the stem made it difficult for the feed rollers to act, which presented difficulties especially at low engine speeds and pump flow rates.

The results of the analysis of excavator-based harvester productivity demonstrate that, at lower engine speeds and hydraulic pump flow rates, the machine does not hold its full power, making base machine speed, complementary boom, and head movements all slower. It should be noted that a lower engine speed provides increased combustion intervals in the engine cylinder and, consequently, reduces the torque and rated power of the machine. Reducing the flow rate of the hydraulic pump reduces the system pressure, and therefore, it reduces the force and delays the machine movements that depend on the hydraulic system. For this reason, the effect of engine speed and hydraulic pump flow rate was more significant at higher volume, where the high weight of the logs required more machine force to perform the search, felling, and processing operations. It should be noted that the operator was accustomed to operating the excavator-based harvester with an engine speed of $2060 \mathrm{rpm}$ and pump flow rate of $300 \mathrm{~L} \mathrm{~min}^{-1}$. It is likely that the use of other combinations or operators familiar with other engine and pump settings could provide improvements in operational performance during the execution of further research on this topic. The operator reported that he was psychologically affected by the fact that engine speed and hydraulic pump flow could be reduced.

Santos et al. (2018) evaluated a Volvo brand excavator-based harvester operating at different engine speeds in a $0.25 \mathrm{~m}^{3}$ tree ${ }^{-1}$ forest stand and concluded that the engine speed regime does not cause significant changes in operational performance. In the research conducted by Ramos et al. (2016), it was found that the engine speed regime in the range of 1800 to $2100 \mathrm{rpm}$ does not affect the operating performance of a sugarcane harvester when operating at speeds up to $4 \mathrm{~km} \mathrm{~h}^{-1}$; however, productivity is significantly influenced at higher speeds. From these results and those presented herein, it can be shown that under certain operating conditions, it is unnecessary to operate the machine at its maximum engine speed and hydraulic pump flow rate.

The reduction in hourly fuel consumption, as the engine speed decreased, was due to lower combustion. However, in the larger tree volume scenario, the decrease was less marked because the excavator-based harvester operating system increased the amount of fuel injected by combustion, trying to compensate for the power loss. With a volume of $0.08 \mathrm{~m}^{3}$ tree $^{-1}$, each combustion required on average an injection of 0.350 , $0.346,0.342$, or 0.339 milliliters of combustion diesel at an engine speed of 2060, 2000, 1950, or $1900 \mathrm{rpm}$ respectively. With a volume of $0.16 \mathrm{~m}^{3}$ tree $^{-1}$, an average injection of $0.374,0.380,0.385$, or 0.391 milliliters of combustion diesel was observed for an engine speed of 2060, 2000, 1950, or 1900, respectively. These results demonstrate that inaccurate engine speed adjustments can lead to increased fuel consumption.

The flow rate of the hydraulic pump influences fuel consumption because the power demanded from the engine at higher flow rates is higher than the power required at low flow rates. The injection pump thus increases the amount of fuel to be injected into the engine cylinder to meet the required power demand.

Regarding the engine speed, the machine behavior for hourly fuel consumption was similar to the results found by Santos et al. (2018), Ramos et al. (2016), and Fiorese et al. (2015). Despite the technical differences between the machines, it is clear that operators work at maximum engine speeds regardless of operating conditions and without regard to high hourly fuel consumption. According to Ackerman et al. (2014), harvester fuel consumption is directly influenced by operator training level.

Regarding the fuel consumption per meter cubic, at low tree volumes, the influence of engine speed 
and hydraulic pump flow is more intense on the hourly fuel consumption when compared to the hourly productivity. However, because of the way fuel consumption is calculated, machine productivity most significantly affects the value of this variable. For this reason, the combination of engine speed and hydraulic pump flow rate that has the lowest fuel consumption value can significantly and negatively affect the operating performance. Prinz et al. (2018) studied logging with the Ponsse Beaver, Ponsse ScorpionKing, and Ponsse Ergo harvesters, operated in general, economical, and production mode. The authors observd the lowest values of fuel consumption when the machine worked in its economical mode, which presented the lowest engine speed (rpm) of all machines in the study to be in economical mode. However, the authors presented relative productivity, not cubic meters per hour.

\subsection{Economic Parameters}

With a volume of $0.08 \mathrm{~m}^{3}$ tree ${ }^{-1}$, the lowest production cost was obtained at the engine speed of $2000 \mathrm{rpm}$ and a hydraulic pump flow rate of $300 \mathrm{~L} \mathrm{~min}^{-1}$. With this combination, there was a reduction in operating costs, due to the reduction in hourly fuel consumption, but there was no significant decrease in operational outcome. At $2000 \mathrm{rpm}$ and $300 \mathrm{~L} \mathrm{~min}^{-1}$, the fuel cost represented $17 \%$ of operating cost, about $1 \%$ less when compared to the expense of the machine running at an engine speed of $2060 \mathrm{rpm}$ and a pump flow rate of $300 \mathrm{~L} \mathrm{~min}^{-1}$. In the research conducted by Santos et al. (2017) and Silva et al. (2014), the cost of fuel represented 8.90 or $24.41 \%$ of the total operating cost, respectively. Despite the differences between these values, which likely arise due to the technical characteristics of the machines and their manufacturers, both values are quite significant when transformed into dollars per hour, which demonstrates the need to adopt measures aimed at reducing the hourly fuel consumption rates for harvesters. With a volume of $0.16 \mathrm{~m}^{3}$ tree $^{-1}$, the lowest production cost was obtained at an engine speed of $2060 \mathrm{rpm}$ and a hydraulic pump flow rate of $300 \mathrm{~L} \mathrm{~min}^{-1}$. This is due to the high operating efficiency of the machine when compared with its overall productivity.

It should be noted that, for the lower values of the independent variables investigated here, the engine of the machine did not overheat, which can prolong the life of the engine and consequently reduce long-term maintenance costs. When the excavator-based harvester was operating at the highest engine speeds, often in the afternoon, it was necessary to stop the machine and to wash the radiator with a water jet to avoid overheating. Also, reducing pump flow decreases hydraulic system pressure, which in turn results in a reduced number of damaged hydraulic hoses.

\subsection{Environmental Parameters}

Carbon dioxide and methane emissions decreased with decreasing engine speed and hydraulic pump flow rate. Similar results were obtained by Prinz et al. (2018), who established that there was a reduction in the amount of $\mathrm{CO}_{2}$ produced with a decrease in engine speed. According to Zhang et al. (2016), the factors that most influence the emission of pollutants during forest harvesting operations are operating yield and fuel consumption, the former being a positive factor and the latter a negative factor.

\section{Conclusions}

In all two volume conditions surveyed, the engine speed and hydraulic pump flow significantly influenced the time of displacement and search operations, felling cut and processing, productivity, hourly fuel consumption, fuel consumption, production cost, and the amount of carbon dioxide and methane emissions.

The combination of an engine speed of $2000 \mathrm{rpm}$ and a hydraulic pump flow rate of $295 \mathrm{~L} \mathrm{~min}^{-1}$ proved to yield the optimal results from a technical, economic and environmental perspective with tree volumes of $0.08 \mathrm{~m}^{3}$ tree $^{-1}$.

To achieve the best results from a technical, economic, and environmental standpoint with average tree volumes of $0.16 \mathrm{~m}^{3}$ tree $^{-1}$, the excavator-based harvester should be operated at $2000 \mathrm{rpm}$ engine speed with a hydraulic pump flow rate of $300 \mathrm{~L} \mathrm{~min}^{-1}$.

Overall, it is advisable to operate the excavatorbased harvester, regardless of individual average volume of trees, at an engine speed of $2000 \mathrm{rpm}$ and a hydraulic pump flow rate of $300 \mathrm{~L} \mathrm{~min}^{-1}$.

\section{Acknowledgments}

This study was financed in part by the Coordenação de Aperfeiçoamento de Pessoal de Nível Superior Brasil (CAPES) - Finance Code 001 and Conselho Nacional de Desenvolvimento Científico e Tecnológico (CNPq).

\section{References}

Abbas, D., Handler, R.M., 2018: Life-cycle of forest harvesting and transportation operations in Tennessee. Journal of Cleaner Production 176(1): 512-520. https://doi.org/10.1016/j. jclepro.2017.11.238 
Ackerman, P., Belbo, H., Eliasson, L., Jong, A., Lazdins, A., Lyons, J., 2014: The cost model for calculation of forest operations costs. International Journal of Forest Engineering 25(1): 75-81. http://dx.doi.org/10.1080/14942119.2014.903711

Barnes, R.M., 1968: Motion and time study: design and measurement of work. 6 ed. New York: John Willey \& Sons, 799 p.

Fiorese, D.A., Marasca, I., Fernandes, B.B., Sandi, J., Ferreira, F., Lanças, K.P., 2015: Desempenho de três tratores agrícolas em ensaios de tração. Revista de Agricultura Neotropical 2(2): 68-76.

Hair Júnior, J.F., Black, W.C., Babin, B.J., Anderson, R.E., Tatham, R.L., 2009: Análise Multivariada de Dados. 6 edição, Porto Alegre: Bookman, 688 p.

Husch, B., Beers, T.W., Kershaw Jr., J.A., 2003: Forest mensuration. 4.ed. Hoboken, New Jersey: John Wiley \& Sons, $443 \mathrm{p}$.

Intergovernmental Panel On Climate Change, 2006. Guidelines for National Greenhouse Gas Inventories: Mobile Combustion. Disponível em: https://www.ipcc-nggip.iges. or.jp/public/2006gl/pdf/2_Volume2/V2_3_Ch3_Mobile_ Combustion.pdf. Acesso em: 04 de setembro de 2018.

Janulevicius, A., Juostas, A., Pupinis, G., 2013: Engine performance during tractor operational period. Energy Conversion and Management 68: 11-19. https://doi.org/10.1016/j. enconman.2013.01.001

Laschi, A., Marchi, E., González-García, S., 2016: Forest operations in coppice: Environmental assessment of two different logging methods. Science of the Total Environment 562: 493-503. https://doi.org/10.1016/j.scitotenv.2016.04.041

Magagnotti, N., Pari, L., Spinelli, R., 2017: Use, Utilization, Productivity and Fuel Consumption of Purpose-Built and Excavator-Based Harvesters and Processors in Italy. Forests 8(12): 485. https://doi.org/10.3390/f8120485
Prinz, R., Spinelli, R., Magagnotti, N., Routa, J., Asikainen, A., 2018: Modifying the settings of CTL timber harvesting machines to reduce fuel consumption and $\mathrm{CO}_{2}$ emissions. Journal of Cleaner Production 197(1): 208-217. https://doi. org/10.1016/j.jclepro.2018.06.210

Ramos, C.R., Lanças, K.P., Lyra, G.A., Sandi, J., 2016: Fuel consumption of a sugarcane harvester in different operational settings. Revista Brasileira de Engenharia Agrícola e Ambiental 20(6): 588-592. http://dx.doi.org/10.1590/18071929/agriambi.v20n6p588-592

Santos, D.W.F.N., Fernandes, H.C., Valente, D.S.M., Leite, E.S., 2018: Desempenho técnico, econômico e ambiental do harvester em distintas rotações do motor. Scientia Forestalis, Piracicaba 46(118): 319-326. http://dx.doi.org/10.18671/ scifor.v46n118.17

Santos, L.N., Fernandes, H.C., Silva, R.M.F., Silva, M.L., Souza, A.P., 2017: Evaluation of costs of harvester in cut and processing of Eucalyptus wood. Revista Árvore 41(5): 9 p. http://dx.doi.org/10.1590/1806-90882017000500001

Silva, E.N., Machado, C.C., Fiedler, N.C., Fernandes, H.C., Paula, M.O., Carmo, F.C., Moreira, G.R., Coelho, E.C., 2014: Avaliação de custos de dois modelos de harvester no corte de eucalipto. Ciência Florestal 24(3): 741-748. http://dx.doi. org/10.5902/1980509815733

Silveira, J.C.M., Fernandes, H.C., Modolo, A.J., Silva, S.L., Trogello, E., 2013: Demanda energética de uma semeadoraadubadora em diferentes velocidades de deslocamento e rotações do motor. Revista Ciência Agronômica 44(1): 4452. https://doi.org/10.1590/S1806-66902013000100006

Zhang, F., Johnson, D.M., Wang, J., Yu, C., 2016: Cost, energy, use and GHG emissions for forest biomass harvesting operations. Energy 114: 1053-1062. https://doi.org/10.1016/j. energy.2016.07.086

(C) 2020 by the authors. Submitted for possible open access publication under the terms and conditions of the Creative Commons Attribution (CC BY) license (http://creativecommons.org/licenses/by/4.0/). 
D. Santos et al. Technical, Economic, and Environmental Parameters of Excavator-Based Harvester in Function ... (205-218)

Authors' addresses:

Diego Weslly Ferreira do Nascimento Santos, PhD

e-mail: diegoweslley89@hotmail.com

Universidade Federal de Lavras

37200-900 Aquenta Sol

Lavras - State of Minas Gerais

BRAZIL

Assoc. Prof. Domingos Sárvio Magalhães Valente, PhD e-mail: sarvio.valente@gmail.com

Assoc. prof. Haroldo Carlos Fernandes, PhD

e-mail: haroldoufv@gmail.com

Assoc. prof. Amaury Paulo de Souza, PhD

e-mail: amaury@ufv.br

Assoc. prof. Paulo Roberto Cecon, PhD

e-mail: cecon@ufv.br

Universidade Federal de Viçosa

36570-900 Aquenta Sol 